\title{
Negotiating Disruption in Carolyne Adalla's Confessions of AIDS Victim and Wahome Mutahi's The House of Doom
}

\author{
Japheth Peter Muindu
}

School of Arts and Social Sciences, Garissa University, Kenya

\begin{abstract}
Increased intellectual interest in the body at the level of lived experience has heightened awareness of bodies as vulnerable entities with the potential to sicken and suffer. Examining the body through artistic responses to the AIDS crisis gives a glimpse of the tensions and connections between the conceptual theoretical body and the material-lived body for AIDS crisis underscores the embodied experience of reality and is therefore subversive of its constructions in discourses power relations. Corporeal representations of AIDS (disease) in literary fiction tends to problematize this social construction as texts engage in exposing inherent fallacies and stereotypes prevalent in social political and economic milieu of the texts through articulating the existential tensions concomitant with the illness. This papers sets out to analyze the mediation of existential disruption by characters in the two novels under study. Through Foucaultian concept of the care of the self and de Certeau's heterological thinking, the paper advances the thesis that Carolyne Adalla's Confessions of AIDS Victim and Wahome Mutahi's The House of Doom provide spaces for the diseased subjects to pursue a quest for existential meaning to transcend the disruption and meaningless wrought on their lives by AIDS
\end{abstract}

Keywords-Disruption, epiphany, alterity, apocalypse, existential meaning.

\section{INTRODUCTION}

HIV disease imposes a heavy weight on the existence of the disease subject. As observed in the previous chapter, Persons Living with HIV disease alienate themselves from the outside world to cushion themselves from stigma and oppressive structures, a sort of alienation that plunges them in existential ennui which has the potential to destabilize the core of the individual and undermine one's sense as an existing being. This situation is best articulated by Rollo May (1950) who describes anxiety as an apprehension cued off by a threat to some value that the individual holds essential to his existence as a personality, 'the experience of the threat of immanent non-being...the subjective individual becoming aware that his existence can become destroyed, that he can lose himself and his world, that he can become nothing' (May,R,1972:50).May's conceptualization of anxiety illuminates the understanding of the ontological disruption facing those living with HIV and AIDS.
Existential framework with its focus on man as a being enmeshed by the structures of his existence is central to understanding the challenges of living faced by human beings. Yalom (1980) posited that, existential philosophy is best suited to assist the HIV infected to adjust and 'look within and attend to their existential condition' while Silvio (2010) pushing the view further, posits that challenges in a human being's life such as induced by life changing situations like chronic illness or debility induce mixed reaction of anxiety, despair, creativity and transcendence. The stigma attendant to HIV/AIDS is illustrative of the extent to which the existential experience of the HIV positives is shaped as they mediate the disruption on their lives as contaminated and disreputable bodies immersed in oppressive discourses where their individuality is only asserted through ultimate demise.

This different mode of being in the world as a consequent of disruptive disease necessitates existential reorientation in 
which the disease subject makes rearrangements and quests for new existential pathways as a being witnessing the collapse of his/ her life-world. This process of life reconstruction in the wake of debilitating illness is also articulated by Gay Becker in her text: Disrupted Lives: How People Create Meaning in a Chaotic World in which she emphasizes the need for the disrupted to re-evaluate their view of what a whole life is, reconcile differences between the past and present so as to create continuity. It is her view that inner chaos and disruption concomitant with disillusionment in expectations in the course of life represent a loss of the future and the restoration of order. It 'necessitates reworking understandings of the self and the world, redefining the disruption and life itself' (pp 4) so as to create order from chaos and render life meaningful. In what follows, I focus on the reactions to HIV disease by the diseased subjects in the two selected texts to explicate their coping strategies from limbo to continuity.

\section{DISCUSSION}

Adalla's novella Confessions of AIDS Victim utilizes the epistolary form as strategy in which Catherine negotiates her predicament, she turns to her bosom friend and to letter writing for support, the friend and the letter writing provide her something to lean on in her hopelessness, a refuge from the terror of AIDS diagnosis. Writing this letter is her introspective turn for support from writing and like Mariama Ba's So Long a Letter, Catherine's alleged letter addressed to her friend Maryline does not from the outset consist of letter-pages to be send directly but rather a notebook more to be put to other, unexplained ends. Its sections appear as chapters instead of letters.

The epistolary text can thus be viewed as exercise, not in letter writing but in self-communication in which Catherine can be seen to be writing to herself to locate the source of her disequilibrium: the reality of her sero-positive status and the introspective search for who infected her. She therefore makes Maryline an imagined sounding board for her selfscrutiny. Her letter is akin to what Obioma Nnaemeka refers to as the exteriorization of an internal dialogue, a dialogue that the author wishes to share with the reader, and pretext for a dialogue with the self' (Muriungi, A, 2005:27).She utilizes letter writing to negotiate her disruption; embracing it as what Mildred Mortimer recognizes as a "dual process of introspection and writing, enclosure and disclosure"(ibid).
Agnes Muriugi highlights the effectiveness of the confessional as a literary ploy to negotiate cultural meanings and significations that cluster around AIDS in Kenya and notes that Catherine' portrayal as a confessor-cum-victim in the text mitigates her culpability as the bringer of her own tragedy over which she is remorseful. Catherine's decision to go public about her status fully aware of the public scum she was exposing herself to is a statement that in some circumstances, declaring the status is the only sane thing to do. Testing positive means she has to re-invent herself and forge a new identity as a strategy of negotiating the inevitable disruption and by 'presenting herself as both confessant and victim, Catherine makes possible the expression of subjectivity and voice denied by the dominant culture in her society while at the same time claiming the worthiness of those infected by HIV/AIDS' (pp 2). She tells Maryline that she writes to occupy herself and also relives her past to circumvent her present predicament. Writing, she informs her, relaxes her, transforms her way of thinking and enables her to come to terms with the fact that she is an AIDS patient.

The fictional duration of the novella seems to mitigate the apocalyptic nature of AIDS since its narration starts after she has been diagnosed but flashes back to secondary school days through university to give hint to the time she might have been infected. Her ex-boyfriend, Brian, the likely culprit, is reportedly going on well with life in the US and his affair with his new girlfriend Denise goes on without the complication normally posed by sero-positive status. Similarly, she herself seems to lead an ordinary life with her boyfriend, Alex, who has since come round to apologizing for ill-treating her over her condition. Alex is still healthy and goes about his job energetically and his lecturer friend has been cleared to travel abroad, hinting to the possibility that he is sero-negative.

These optimistic portrayals and the fact that their affair has been going steady for over three years seems to negate the hegemonic rhetoric that frames the illness as a death sentence, with those infected expected to make exit from the world not long after the infection, a rhetoric that ignores the scientific facts of the pandemic. Her acceptance of her situation emboldens her and any tendency to condemn her for her condition is redeemed by the courage she exhibits in confessing her condition to Brian and advising him to get tested for the antibodies. She also takes occasional strolls to relax the tension imposed on her by her condition, on top of proper dieting to buttress her immunity, and is upbeat that 
the medical researchers will come up with an AIDS cure and vaccines for prevention.

Catherine finds solace in confiding in her friend Maryline, for confiding in others allays pain. There is a hint in the novella that this correspondence will continue since she hopes to include more details in her next letter and her friend will sure reply to egg her on against adversity. Optimism and affirmation of life in the face of menacing illness, not the inevitable doom, is thus underscored in the novella. Catherine's wish that the content of her letter were made public for the benefit of all is an indication that this is no ordinary communication but a burning urge to go public about her condition as a panacea against AIDS associated stigmatization. Catherine seems to embrace Paul Monette's conviction, which was born out of his experience with AIDS that: 'If my life has been useful enough to help people understand that they are not alone, and then I know those people will go off and help others. That is how we change the world' (Monette, P, 1991:46). Monette further adds that it would give him satisfaction to die knowing that his was a kind of first voice telling the story of what AIDS did to the infected.

In The House of Doom, AIDS illness is presented a s a marginal category out of which individuals reconstruct their selfhood as they enact their illness. In his heterological thinking, de Certeau 'recovers unexpected resonances of effectiveness in even the powerless' and 'urges us to look for capabilities on the margins where ordinarily ideology suggests we will find only dependency and subservience' (Terdiman, R, 2001:416). On his part Foucault proposes that 'we escape as much as possible from the type of relationship that society proposes for us and try to create, in the empty space where we are, new relational possibilities' (Foucault, M, 1997b:160). Foucault perceives of the void such as that engendered by terminal illness as 'a space at the threshold of constituent praxis' (ibid) and insists that an experience is something that one comes out of transformed.

In The House of Doom, Mbela conjures epiphany from his illness experience as he endeavors to quest through chaos. He disrupts hegemony by boldly exposing hypocritical response to AIDS rife in the society. Not taking life for granted any more, he is out to live his day as if it were the last one in preparation for the inevitable. Before this day of his corporeal extinction, he seeks what will quarantine him continuity. He wants to love and to be loved, and Wambui's appreciation of him makes his life worth living. Like Lavina and Giorgio's relationship in The Cruciblefor Silver and
Furnace for Gold, Mbela and Wambui's romantic rebirth is meant to affirm life and postpone doom and death. He invests in the fulfilling intimacy with Wambui, the only person who understands and empathizes with his predicament to transcend the apocalypse associated with his condition. As mentioned elsewhere, their bold public declaration of love and marriage plans infuse an antiapocalyptic temper that privileges life where doom and death compete for supremacy. His enactment of illness after the narrow escape from contrived accident seem to tally with de Certeua's idea of the 'epistemological status of alterity' (Terdiman, R, 2001) where meaning arises from the margin as the disadvantaged reconstruct their selfhood.

His illness experience leads to acute awareness of his impending destruction, its decomposition, its explosion and enables 'its conversion to something else, a conversion that marks the shift from destination to constitution. In reconstituting himself, Mbela is inclined to more altruism and quests for continuity beyond his inevitable physical extinction by arranging to bequeath his books to a local secondary school, which can be read as an attempt to 'create order out of the chaos and thereby render[his] life meaningful'(Becker,G,1998:4).

AIDS diagnosis can be read as an immersion into Joseph Campbell's mythical innermost cave from where a hero comes back with an elixir in form of a treasure won on a quest, or a realization that a special world exists and can be survived, or sometimes 'it is just coming home with a good story to tell'(Vogler,C,2007:274). The diseased subject may not be entering the Campbellian labyrinths to combat mythical beasts but may enter his innermost cave by going into their own minds as they quest through the disruption wrought in their lives by HIV illness.

\section{CONCLUSION}

These two HIV/AIDS novels seem to exhibit a narrative ambiguity in their dichotomous presentation of HIV/AIDS as manageable, chronic illness, on the one hand, and as an apocalypse, a deadly calamity on the other. Diseased subjects in the novels are seen to adjust themselves to the difficulties they face in their disrupted lives motivated by the necessity to resist the perception of their condition as a death sentence. Though the two novels focus on characters who have become increasingly isolated in their condition, they also describe the lives of these characters as they actively interface with the 
larger communities in which they exist and navigate their way from limbo to continuity.

\section{REFERENCES}

[1] Adalla, Carolyne.Confessions of an AIDS Victim.Nairobi: Heinemann, 1993

[2] Becker, G. Disrupted Lives:How People Create Meaning in a Chaotic World.Berkeley: Califronia Press, 1998.

[3] Monette, Paul. Half Way Home.New York: Avon, 1991.

[4] May, R J. Toward a New Earth: Apocalypse in the American Novel.Notre Dame:University of Notre Dame Press, 1972.

[5] Terdiman, R. "The Marginality of Michel de Certeau".The South Atlantic Quarterly, Vol.100,Number 2, Spring 2001, pp.399-421

[6] Muriungi, Agnes. "Romance, Love and Gender in Times of Crisis: HIV/AIDS in Kenyan Popular Fiction" (The University of Witwatersrand: Unpublished PhD Dissertation, 2005)

[7] Wahome Mutahi, Wahome. The House of Doom.Nairobi: Africawide Network, 2004 